\title{
Constitutional Complaint in Ukraine: The Interrelation Between the Protection of Subjective Civil Rights and Constitutional Control
}

\author{
Oleksandr D. Krupchan ${ }^{1,}$, , Volodymyr V. Kochyn ${ }^{2}$, Vitalii I. Zaporozhets ${ }^{2}$ and \\ Mykyta V. Bernatskyi ${ }^{2}$
}

\begin{abstract}
${ }^{1}$ Department of Directorate, Academician F.H. Burchak Scientific and Research Institute of Private Law and Entrepreneurship of the National Academy of Legal Sciences of Ukraine, Kyiv, Ukraine

${ }^{2}$ Department of Methodology of Private Law Research, Academician F.H. Burchak Scientific and Research Institute of Private Law and Entrepreneurship of the National Academy of Legal Sciences of Ukraine, Kyiv, Ukraine
\end{abstract}

\begin{abstract}
The real possibility of judicial protection of individual rights and freedoms is a key element of effective legal regulation, as well as the manifestation of the rule of law. The new institution of the constitutional complaint lies in a rather specific plane, being both a part of the national system of protection of individual rights and freedoms and an element of constitutional control that ensures the supremacy of the Constitution of Ukraine. The relevance of this study is conditioned by the right of a citizen to complain about the mechanism of legal regulation, taking the provisions of the Constitution as an example. The purpose of the study is to consider the specific features of the interrelation between the protection of subjective civil rights and constitutional control. This study analyses the theoretical aspects, legislative regulation, and practice of the Constitutional Court of Ukraine. It was concluded that subjective rights and interests established by law might be violated, unrecognised or challenged only at the stages of legal implementation or enforcement.
\end{abstract}

Keywords: Rule of law, legislation, legal dispute, Constitutional Court, human rights.

\section{INTRODUCTION}

In general, the legal regulation of public relations comes down to such stages as legal regulation (consolidation of legal relations in the legal provision), legal implementation (active or passive actions of the parties) and legal application (involvement of authorised persons in order to properly exercise rights and obligations). The main element of both effective legal regulation and the disclosure of the principle of the rule of law is the real possibility of judicial protection of individual rights and freedoms.

Article 55 of the Constitution of Ukraine (Decision of the... 2009) (hereinafter referred to as "the Constitution"; "the Fundamental Law") is developed in a way that allows to single out the following: the general principles of judicial protection (Part 1); guarantees of the right to appeal in court against decisions, actions or omissions of public authorities, local governments, officials and officers (Part 2); a separate right to apply for protection of one's rights to the Commissioner for Human Rights of the Verkhovna Rada of Ukraine (Part 3); guarantee of the right to file a constitutional complaint to the Constitutional Court of Ukraine on the grounds established by this Constitution

${ }^{*}$ Address correspondence to this author at the Academician F.H. Burchak Scientific and Research Institute of Private Law and Entrepreneurship of the National Academy of Legal Sciences of Ukraine, Kyiv, Ukraine;

Tel: (044) 28670 31; E-mail: od.krupchan@nuos.pro and in accordance with the procedure established by law (Part 4); and the right, after using all domestic remedies, to apply for protection of one's rights and freedoms to the relevant international judicial institutions or to the relevant bodies of international organisations of which Ukraine is a member or participant (Part 5); finally, the right by any means not prohibited by law to protect one's rights and freedoms from violations and unlawful encroachments (Part 6).

The new institution of the constitutional complaint lies in a rather specific plane, being both a part of the national system of protection of individual rights and freedoms and an element of constitutional control that ensures the supremacy of the Constitution of Ukraine. Thus, the constitutional proceedings differ from the provisions of Part 2 of Article 124 of the Constitution of Ukraine, according to which "the jurisdiction of courts extends to any legal dispute...".

The Constitutional Court of Ukraine within its powers to consider a constitutional complaint, referring to the factual circumstances of the case (legal dispute), evaluates the constitutionality of the relevant legal provision, which was the basis for resolving this dispute, thereby assessing the entire mechanism of legal regulation. The exercise of subjective civil right includes such powers as the right to one's own actions, the right to the actions of others and the right to protection of a violated, unrecognised or disputed right. 
As a result, Part 1 of Article 16 of the Civil Code of Ukraine makes provision for the right of people to go to court to protect their personal non-property or property rights and interests. Thus, the precondition for the right to go to court is the awareness of a person that his/her respective subjective right has been violated.

In the legal literature, a legal dispute (or an issue on law) is considered in the following aspects: 1) it is identified with a breach or obstacles to the exercise of a right; 2 ) is described as a legal relationship (security, organisational and security, such that arises as a result of the presentation of the claim, "conflict") or a certain state of the regulatory relationship; 3 ) a means of protection, i.e. it is considered that it acquires the properties of a legal category only from the moment of its application by the interested person in a certain order; 4) the legal structure developed as a result of accumulation of several legal actions (also inaction) of the parties of civil legal relations; 5) is a dispute, discrepancy of wills, conflicts between the subjects of legal relations regarding their rights and obligations; 6 ) the statement of at least one of the parties to the dispute about the existence of a certain substantive legal relationship between the parties to the dispute and the violation or challenge of this relationship, the applicant, the subjective right of another party to the dispute (Smolkova et al. 2018).

Therewith, the court of general jurisdiction decides on the case in accordance with the current legal regulation, having only some opportunities to evaluate it for constitutionality. In view of this, this study aims to consider the specific features of the relationship between the protection of subjective civil rights and constitutional control, because "having passed" all stages of the mechanism of legal regulation, a person has the right to submit a complaint regarding this mechanism, taking the provisions of the Constitution as an example.

\section{CHARACTERISTICS OF THE RIGHT TO PROTECTION OF SUBJECTIVE CIVIL RIGHTS}

Civil law protection of rights and interests is considered as an institution of civil and civil procedural law. As a result, some scholars consider it an element of subjective civil rights, others - an isolated subjective right (Dąbrowski 2019). O.O. Kot summarised the basic concepts of understanding the concept of protection of rights: 1) the theory of function (T.I. Illarionova, N.P. Aslanyan) - the function of law, expressed in the protected influence of provisions aimed at restoring the right to compensate for the violated interest, to stop illegal actions that impede the exercise of rights or the rule of law; 2) protection of civil rights through the category of "measures" (Yu. I. Basin, Ya. M. Shevchenko, M.K. Suleimenov, etc.) - a system of measures stipulated by law to combat the breach, based on state coercion and aimed at ensuring the inviolability of the right and eliminating the consequences of its violation; 3 ) theory of activity (T.M. Pidlubna, Yu. D. Prytyka, R.O. Stefanchuk, G.P. Arefiev, etc.) - as the activity of competent bodies (law enforcement activity) in order to restore the violated, unrecognised or disputed subjective right and interest. In addition, V.O. Tarkhov identifies protection as a measure of permissible behaviour, while Yu.M. Andreev identifies it as a function through the application of competent authorities of civil sanctions (Sakara 2017).

The theoretical and legislative model of protection of civil rights and interests is actually similar to the exercise of rights and makes provision for the independence of the right. Moreover, the moment of the right to protection is also important, as it is necessary to establish whether the person seeking protection was in the relevant dispute (Ruling of the... 2018c). In accordance with Part 1 of Article 4 of the Civil Procedural Code of Ukraine, every person has the right to seek redress for their violated, unrecognised or disputed rights, freedoms or legitimate interests. In turn, the right to go to court in the interests of others or state or public interests is provided by law (Part 2 of Article 4 of the Civil Procedural Code of Ukraine)

Separate regulation of participation of the said persons in the trial is provided in Article 56-57 of the Code of Civil Procedure of Ukraine. These provisions mainly regulate the participation of the bodies to which this right has been granted in the court proceedings. However, the only precondition is provided for persons - in cases established by law. With regard to collective rights, it is a matter, first of all, of Paragraph 9 Part 1 of Article 25 of the Law of Ukraine "On Consumer Protection", in particular the right of public consumer organisations to apply to court demanding the recognition of the actions of the seller, the manufacturer (enterprise performing their functions) or the executor as illegal for an indefinite number of consumers and termination of these actions. Notably, the general law "On Public Associations" does not have a separate right to apply to the court; instead, it makes provision for the right to apply to public authorities in accordance with the procedure prescribed by law (Paragraph 2, Part 1 of Article 21). 
Please note that the provision of Part 1 of Article 56 of the Civil Procedural Code of Ukraine is formulated in such a way that only "public authorities, local governments must provide the court with documents confirming the existence of statutory grounds for going to court in the interests of others" (similar to Article 53 of the Civil Procedural Code of Ukraine). However, the practice of confirming procedural powers contradicts this rule. Thus, the decision of the Supreme Commercial Court of Ukraine dated 21.12.2016 in case No. 922/2110/16 (Ruling of the Second... 2018d) established that the plaintiff public organisation failed to prove its right to represent in the disputed legal relationship and failed to provide evidence of violated civil rights or interests, which served as an independent ground for refusing to satisfy the claims. The practice of the Supreme Court is similar, according to which it is possible for a public organisation to apply (even without the status of a legal entity) exclusively in its own interests and not in the interests of members (paying attention to the representative function of the public organisation) (decision of the Supreme Court of November 7, 2018, in case No. 804/6859/16) (Berestova 2018).

According to the decision of the Constitutional Court of Ukraine on the constitutional complaint of the Association "House of Music Authors in Ukraine" regarding the official interpretation of the provisions of Paragraph 7 of Part 1 of Article 5 of the Law of Ukraine "On Judicial Fees" in conjunction with the provisions of paragraph "d" of Part 1 of Article 49 of the Law of Ukraine No. 12-rp/2013 "On Copyright and Related Rights" of 28.11.2013 (case No. 1-17/2013) (Gubska 2014) "... a public organisation may protect in court the personal non-property and property rights of both its members and rights and legally protected interests of other persons who applied to it for such protection, only if such authority is provided in its statutory documents and if the relevant law determines the right of a public organisation to apply to the court to protect the rights and interests of others" (subpara. 3 para. 2.6).

Thus, the Constitutional Court of Ukraine recognises the specialised activities of socially useful non-entrepreneurial associations and the possibility of their participation in the so-called "human rights relations". In the legal literature, the subjects of human rights relations are those persons who have a legal relationship with the subject (object) of human rights relations, i.e., have legal personality (competence), which allows them to act as participants in this relationship. Therewith, it is evident that the scope of subjects of human rights activities is wider than the subjects of the right to protection of human rights 'Stavniychuk et al. 2019'.

At present, there are no proper civil procedural tools to protect the rights and interests of an indefinite number of persons in Ukrainian legislation, which, according to T.V. Stepanenko, is a complex intersectoral formation of legal provisions governing public relations through existing legal means to protect public interests and positive changes in public life (Council of Europe... 2013). Otherwise, the exercise of the right to go to court by such persons is possible within the framework of a group or other representative claims, which leads to a court decision in cases of protection of the rights and interests of an indefinite number of persons. Thus, a class action is aimed at protecting private interests, a claim in the interests of an indefinite number of persons is aimed at protecting the public interest, and a derivative claim is aimed at protecting the private-public interest (Umbetov et al. 2020). As a result, within the framework of judicial protection, the following claims for protection of collective interests can be distinguished: group, indirect, claim of co-plaintiffs and independent claim of a legal entity (for the indirect protection of members/participants of a legal entity). In this case, the key to the proper resolution of the dispute is to establish the scope of persons whose rights and interests will be protected, or a detailed definition of the interest, which is protected by law in order to give the decision a prejudicial nature.

The exercise of the right to protection of the rights of a group of persons or an indefinite scope of persons is considered within the procedural institution of a class action, which allows applying the consequences of its consideration, including to persons who did not take part in such action, taking into account that all persons whose interests were resolved by the relevant court decision to have equal rights and obligations to implement such a decision. This method of protecting public rights was known to Roman law (The Digest of Justinian, Book One, Title IV "On claims brought on behalf of or against a community"). Currently, in the countries of continental law, a class action was introduced in 1994 in the Netherlands, in 1995 - in Portugal, in 2001 - in Spain, in 2002 - in Sweden. Other European countries are more restrained towards this institution (European Court of... 2007a).

I.E. Berestova draws attention to the fact that it is the plaintiff representing the group - either directly a 
member of the group or a public organisation or government body - who applies to the court with a group claim; instead, the filing of a claim (as a procedural action) is made by the plaintiff personally and through a representative. Thus, the task of the class action is to influence the behaviour and motivation of the defendant to voluntarily restore the violated rights of group members (Savchyn 2018). In this regard, it should only be added that the application of a non-entrepreneurial company (including without the status of a legal entity) allows to properly establish the interest pursued by such a plaintiff.

On September 30, 2016, the Law of Ukraine "On Amendments to the Constitution of Ukraine (Regarding Justice)" (Ruling of the... 2018a) entered into force, and one of its main novelties was the introduction of the constitutional complaint in Ukraine as another domestic remedy for violated rights. Considering the legal significance of the decision of the Constitutional Court of Ukraine, the consequences of the constitutional complaint can be considered both as protection of the subject of the appeal and as a tool to protect an indefinite number of persons (at least as a prerequisite for such protection). Thus, according to Article 151 of the Constitution of Ukraine, the Constitutional Court of Ukraine decides on the compliance (constitutionality) of a law of Ukraine with the Constitution on a constitutional complaint of a person who believes that the law of Ukraine applied in the final court decision in this person's case contradicts the Constitution. A constitutional complaint may be filed if all other domestic remedies have been exhausted.

As is evident from the mentioned constitutional provisions, a statutory model of a constitutional complaint has been introduced in Ukraine, which is related to the consideration of a particular case in the courts in the judicial system of Ukraine. According to this model, only the law of Ukraine, which underlies the adoption of an individual act - the final court decision, is subject to appeal, while such a decision, if the constitutional complaint is satisfied, will be reviewed by courts of general jurisdiction in accordance with procedural legislation.

Appeals of persons with individual constitutional complaints about the laws that were applied in the final court decision in their case implement not only the possibility of judicial review of a person's case in exceptional circumstances, in connection with the recognition of unconstitutional provisions of law (private interest), but can also become an effective mechanism towards the improvement of the legislation of Ukraine, bringing it into line with constitutional principles and guarantees (ensuring the public interest) (Borysova et al. 2019).

The provisions of Article 55 of the Constitution of Ukraine guarantee everyone the right to file a constitutional complaint with the Constitutional Court of Ukraine on the grounds established by this Constitution and in accordance with the procedure prescribed by law. However, the provision of Paragraph 2 of Article 56 of the Law of Ukraine "On the Constitutional Court of Ukraine" (European Court of... 2004) (hereinafter referred to as "the Law") excludes legal entities under public law from the list of subjects of the right to a constitutional complaint.

Following the instructions of the European Court of Human Rights, legal entities under public law that enjoy sufficient institutional and operational independence may also have the right to file the complaint (Islamic Republic of Iran Shipping Lines v. Turkey (European Court of... 2007b), Ukraine-Tyumen v. Ukraine (Ruling of the... 2018b), Unédic v. France (European Court of... 2010)).

The European Court of Human Rights states, inter alia, that a legal entity "claiming to be the victim of a violation by one of the High Contracting Parties of the rights set forth in the Convention or the protocols thereto" may apply to a court if such legal entity is a "non-governmental organisation" within the meaning of Article 34 of the Convention. The term "governmental organisation", as opposed to "non-governmental organisation", refers to legal entities that take part in the exercise of a power or perform a public function under the control of the Government (see decision in the case of Radio France and Others v. France (European Court of... 2000)). In deciding whether a legal entity falls into one of the above categories, the European Court of Human Rights must take into account its legal status, the nature of its activities, the context of such activities and the degree of independence of the individual from public authorities.

In the case of Ukraine-Tyumen $v$. Ukraine, the European Court of Human Rights notes that under Ukrainian legislation and the provisions of the founding treaty, the applicant is institutionally autonomous. In its activities, it is guided by the legislation governing the activities of companies and is under the control and management of its founders (see paragraphs 9 and 18 above). Even assuming that the State still owned 
approximately one-third of the applicant's share capital, no evidence was adduced that the State had an advantage in the management of the enterprise over other shareholders. Moreover, there is nothing in the present case to show that the applicant pursues activities other than business, although some provisions of the memorandum of association can be interpreted as endowing the applicant with a public function, namely the function of implementing "intergovernmental decisions" in the field of entrepreneurial cooperation. The Court, therefore, concludes that the applicant is a "non-governmental organisation" within the meaning of Article 34 of the Convention on Human Rights and Fundamental Freedoms.

\section{SIGNS OF INADMISSIBILITY OF A CONSTITUTIONAL COMPLAINT AND EXERCISE OF THE RIGHT TO A CONSTITUTIONAL COMPLAINT}

A constitutional complaint may be filed if the person has exhausted all domestic remedies (in the presence of a court decision rendered in the appellate review, which has entered into force, and in the case of the possibility of a cassation appeal stipulated by law - a court decision rendered in the cassation review). Evidently, the reason for establishing such a requirement is the function of the constitutional complaint as an emergency and subsidiary remedy, because under current procedural legislation the court of general jurisdiction, upon considering the case and concluding that a law or other legal act contradicts the Constitution of Ukraine, may not apply such law or other legal act, and instead apply the provisions of the Constitution of Ukraine as directly applicable provisions. In this case, the court, after making a decision in the case, appeals to the Supreme Court to resolve the issue of submitting to the Constitutional Court of Ukraine a petition regarding the constitutionality of a law or other legal act referred to the jurisdiction of the Constitutional Court of Ukraine ("The case file demonstrates that the Supreme Court of Ukraine by a decision of September 12, 2017, overturned the decision of the Supreme Administrative Court of Ukraine of January 30, 2017, and sent the case for retrial to the Supreme Administrative Court of Ukraine. Thus, the petitioners did not exhaust all domestic remedies." The decision of the First Chamber of Judges of the Second Senate of the Constitutional Court of Ukraine № 59-1(II)/2018 of April 12, 2018 (Ruling of the... 2018a))).

As a rule, a person is quite limited in the time of filing a constitutional complaint, and therefore the provisions of Paragraph 2 of Part 1 of Article 77 of the Law one of the conditions for the admissibility of a constitutional complaint is a three-month period for filing a constitutional complaint from the date of entry into force of the final court decision, in which the law of Ukraine is applied (its individual provisions). However, the legislator made provision for certain exceptions to the general rule. Thus, a constitutional complaint may be accepted outside the requirements established by Paragraph 2 of Part 1 of this Article, if the Court finds its consideration necessary for reasons of public interest.

M.V. Savchin identifies three factors that may lead the Court to make such a decision, namely:

1. the subject of the constitutional complaint concerns a certain institutional problem that exists in the national legal order and needs to be resolved, as its further pendency creates typical violations of human rights and freedoms, which must be guaranteed by constitutional means;

2. violation of a fundamental right guaranteed by constitutional means has such grave and inevitable consequences for its bearer (even if they do not constitute a specific institutional problem for the national legal order) given the violation of fundamental principles of due process that it requires immediate intervention of the Court by reviewing the constitutional complaint;

3. there is a need to unify or change the established practice of the Court, as the materials of the constitutional complaint demonstrate that the existing practice of applying the provisions of the Constitution of Ukraine results in excessive and disproportionate restriction of law, which is the subject of the constitutional complaint (Resolution of the... 2018a).

The law gives the Court the right to refuse to initiate constitutional proceedings, declaring a constitutional complaint inadmissible if the content and requirements of the constitutional complaint are manifestly unfounded or there is an abuse of the right to file a complaint.

The analysis of the Court's practice in considering constitutional complaints, in particular the so-called negative rulings, allows to identify certain criteria of obvious unfoundedness, namely: 
1) allegations of differences in judicial practice, disagreement with court decisions in the case, incorrect application of substantive law or procedural violations by courts, etc. cannot be used as a basis for substantiating the unconstitutionality of the provisions of the law of Ukraine. ("...the petitioner does not agree with the decision of the Supreme Court of Ukraine, pointing to the illegal refusal to admit his case to the proceedings. However, disagreement with court decisions is also not a ground for initiating constitutional proceedings in the case" (ruling of the Second Senate of the Constitutional Court of Ukraine No. 17-y(II)/2018 of June 62018 (Decision of the... 2004)).

"The subject of the right to a constitutional complaint actually does not agree with the decision of the Supreme Court of Ukraine and points to the illegal refusal to admit it to justice. However, disagreement with court decisions is also not a ground for initiating constitutional proceedings in the case" (ruling of the Second Senate of the Constitutional Court of Ukraine No. 18$y($ II)/2018 of June 6, 2018 (Resolution of the... 2018));

"...the issue of application of the laws of Ukraine by courts does not belong to the powers of the Constitutional Court of Ukraine, which the latter repeatedly emphasised and noted that law enforcement activity, which lies in the individualisation of legal provisions on specific subjects and specific cases, i.e., in establishing the facts and selection of legal provisions that correspond to these circumstances, is a component of law enforcement and do not belong to the powers of the Constitutional Court of Ukraine (decisions No. 15-y/2010 of March 31, 2010, No. 73-y/2014 of July 3, 2014, No. 14-y/2016 of February 24, 2016" (decision of the Second Senate of the Constitutional Court of Ukraine No. 23$y($ II)/2018 of June 26, 2018 (Decision of the... 2013)));

2) improper legislative regulation or its absence, the need to fill gaps in regulations, and inconsistency of legislative acts cannot be grounds for opening constitutional proceedings in the case ("...the author of the petition points to the imperfection of the legislation in the field of legal regulation of registration of a person's place of residence. However, the issue of improving the legislation is not within the jurisdiction of the Constitutional Court of Ukraine" (ruling of the Second Senate of the Constitutional Court of Ukraine No. 35$y($ II)/2018 of September 26, 2018 (Resolution of the... 2018b)));

3) the assumptions of the subjects of the right to a constitutional complaint cannot be considered as arguments to confirm the unconstitutionality of the provisions of the law of Ukraine because, as noted earlier, the constitutional complaint must indicate the violated right and the applicant must be a victim, using the terminology of the European Court of Human Rights. ("Assumptions cannot be considered arguments to confirm the unconstitutionality of legal acts or their individual provisions" (rulings of the First Chamber of Judges of the First Senate of the Constitutional Court of Ukraine No. 152-1(I)/2018, No. 1491(I)/2018 of April 25, 2018.

"... the content of the constitutional complaint suggests that, arguing her allegations about the unconstitutionality of the disputed provisions of Law No. 76, /the citizen/ refers to Article 22 of the Constitution of Ukraine, but does not indicate which of her constitutional rights was violated as a result of these provisions. Since Article 22 of the Constitution of Ukraine defines guarantees for the exercise of constitutional rights and freedoms of human and citizen, it cannot be an independent argument for substantiating allegations of unconstitutionality of the law of Ukraine (its separate provisions)." (ruling of the Second Senate of the Constitutional Court of Ukraine No. 1-yn(II)/2018 of July 16, 2018 (Decision of the... 2018))).

4) citing the provisions of the Constitution of Ukraine, the content of the laws of Ukraine, other regulations, legal positions of the Court and decisions of the European Court of Human Rights without arguing the inconsistency of the Constitution of Ukraine disputed provisions of the law of Ukraine is not considered proper justification. ("The petitioner in the constitutional 
complaint cites the provisions of the Constitution of Ukraine and laws of Ukraine, the Convention, the decision of the European Court of Human Rights. However, quoting without arguing inconsistency with the Constitution of Ukraine disputed provisions of the law does not constitute substantiation of allegations of their unconstitutionality" (ruling of the First Senate of the Constitutional Court of Ukraine No. 55$\mathrm{y}(\mathrm{I}) / 2018$ of November 7, 2018 (Steinberger 1994)));

5) the lack of demonstration of the connection between the rule of law and the restriction of law gives grounds to conclude that the constitutional complaint is clearly unfounded, and therefore the Court quite fairly formulated a legal position that a person who applies to the Court must not only indicate, but also reasonably prove how exactly the law (its individual provisions) restricts or violates a specific constitutional right of this person and that such a restriction does not comply with the Constitution (is unconstitutional) ("Lack of connection between the disputed provisions of the Law and the relevant provisions of the Constitution of Ukraine). This is a ground for refusing to initiate constitutional proceedings in accordance with Paragraph 4 of Article 62 of the Law of Ukraine "On the Constitutional Court of Ukraine" - inadmissibility of a constitutional complaint" (ruling of the Second Senate of the Constitutional Court of Ukraine No. 10-y(II)/2018 of June 4, 2018 (Horodovenko, Pashkov, and Udovyka 2020)). In accordance with Article 1511 of the Constitution of Ukraine, paragraph 6 of Part 2 of Article 55 of the Law of Ukraine "On the Constitutional Court of Ukraine", a person appealing to the Constitutional Court of Ukraine must not only indicate but also substantiate how exactly the challenged law (its separate provisions), applied in the final judgment in the person's case, violates their right guaranteed by the Constitution of Ukraine (ruling of the First Senate of the Constitutional Court of Ukraine No. 20-y(I) of June 13, 2018 (European Court of... 2008))).

The legal nature of the constitutional complaint, the nature of the issues considered by the Constitutional Court of Ukraine, the specific features of the constitutional proceedings and several other objective factors determine the special procedure for preliminary analysis of constitutional complaints and consideration on the merits. An important stage is the preliminary examination of a constitutional complaint when it is assessed whether the complaint meets the formal requirements imposed on it by the relevant legislative provisions.

Analysis of the practice of constitutional jurisdiction of foreign countries suggests that a considerable number of complaints that do not meet certain requirements are returned at the stage of preliminary inspection, and therefore the primary duty to interpret and clarify these requirements rests with their secretariats (apparatus). The legislator, upon providing individuals and legal entities with access to constitutional justice, determined the procedure for appealing to the Constitutional Court of Ukraine, the mechanism for carrying out constitutional proceedings, as well as the powers of the Court and its Secretariat.

Thus, the provisions of the Law authorise the Secretariat of the Constitutional Court of Ukraine (hereinafter referred to as "the Secretariat") to carry out a preliminary examination of appeals received by the Court (paragraph 6 of Part 2 of Article 44, Part 2 of Article 57). Neither the judge nor the panel of judges of the Constitutional Court of Ukraine decides on the compliance of a constitutional complaint with the formal requirements of the Law, as this power is clearly assigned to the Secretariat by the legislator. They may not replace the specified procedure and the subject of power, to whose competence the Law refers the adoption of relevant decisions.

In view of the above, the absence of any of the above components in the application means that it does not meet the requirements of the Law and is subject to return by the head of the Secretariat as stipulated in Part 2 of Article 57 of the Law. If the constitutional complaint does not meet the requirements of the Law, the head of the Secretariat returns it to the subject of the right to a constitutional complaint (Part 3 of Article 57 of the Law). Chambers, senates, and the Grand Chamber of the Court, within limits and in accordance with the procedure established by the law, decide, inter alia, on the opening of constitutional proceedings in a case and consider complaints on the merits.

Returning to the requirements of the Law on constitutional complaints, they are established by the provisions of Articles 55, 56, and Part 1 of Article 74 of the Law, namely: 
Based on the legal definition of the concept of "constitutional complaint", the prescription of the first part of Article 55 of the Law defines the following mandatory components that form the concept of constitutional complaint:

- it is a written request,

- the raised issue concerns the constitutionality of the law of Ukraine and not another act (According to Part 1 of Article 151-1 of the Constitution of Ukraine, Paragraphs 5, 6 of Part 2 of Article 55, Part 1 of Article 56 of the Law of Ukraine "On the Constitutional Court of Ukraine" a person may file a complaint only regarding the constitutionality of the law of Ukraine, and not another act (ruling of the First Senate of the Constitutional Court of Ukraine No. 20-y(I)/2018 of June 13, 2018 (European Court of... 2008))),

- the impugned law (its separate provisions) was applied in the final court decision in the case of the complainant (Constitutional complaint on verification of compliance with the Constitution of Ukraine that does not meet the requirements of Part 1 of Article 55 of the Law). As a general rule, for the purposes of filing a constitutional complaint, a final court decision should be understood as a court decision adopted as an appellate review, which has entered into force, and in the case of a statutory appeal, a court decision rendered in a cassation review. Therewith, to effectively protect the violated rights of the applicants, the Court repeatedly considered acts of the courts of the first instance that are not subject to appeal as a final court decision in the case (for example, decisions of investigating judges under the Civil Procedural Code). Thus, the significance of the issues decided by investigative judges and the possibility of significant influence on the scope of constitutional human rights allow a person to apply to the Constitutional Court of Ukraine even when the case has not yet been considered. The phrase "in their case" indicates that the application of the law of Ukraine by the court should concern exactly the person in respect of whom the court decided the issue of their rights or obligations, and therefore all other persons in respect of whom the court did not resolve such issues cannot file a constitutional complaint.

2) As in any other legal document, the constitutional complaint must indicate the formal components: surname, name, patronymic (if any) of the applicant, address of registered residence (for a foreigner or stateless person - a place of residence); for a legal entity - its full name and location, as well as means of communication, email address, if any.

3) Addressing the Constitutional Court, the applicant must decide on the need for the participation of representatives in that applicant's case; the Law does not require the participation of a representative and gives the applicant the opportunity to defend his or her rights and legitimate interests in constitutional proceedings. Therefore, the next requirement for a constitutional complaint is to indicate information about the authorised person acting on behalf of the subject of the right to a constitutional complaint (if any), which certifies the right to represent the interests of the subject of the right to a constitutional complaint in the Constitutional Court of Ukraine (for example, power of attorney or warrant).

4) In the text of the petition, the subject of the right to a constitutional complaint must indicate a summary of the final court decision, in which the relevant provisions of the law of Ukraine were applied.

5) The next requirement for a constitutional complaint is the need to specify in it a description of the course of consideration of the relevant case in the courts.

6) The petitioner must determine the subject of constitutional review - indicate the specific provisions of the law of Ukraine to be reviewed for compliance with the Constitution of Ukraine, and specific provisions of the Constitution of Ukraine, for which the law of Ukraine is to be reviewed. Therewith, the Constitutional Court has repeatedly emphasised that it is insufficient to indicate only the articles of the relevant law of Ukraine or the Constitution of Ukraine, as the vast majority of them consist of several parts that contain independent content (The subject of the right to a constitutional complaint must clearly define the subject of the constitutional review, and it is insufficient to merely indicate the articles of the relevant law of Ukraine, or the Constitution of Ukraine as specific parts of these articles should be indicated as well, since each of them 
has its own content (ruling of the First Chamber of Judges of the Second Senate of the Constitutional Court of Ukraine No. 1741(II)/2018 of May 22, 2018 (Dzera, Luts, and Kuznetsova 2008))).

7) Indicates the absence of a mandatory component of the constitutional complaint, failure to state in the petition any motivation for the unconstitutionality of the law of Ukraine, simply declaring it unconstitutional, only expressing disagreement with court decisions, actions of officials and officers, etc. Therefore, the author of the constitutional complaint must provide reasoning regarding the unconstitutionality of the law of Ukraine (its individual provisions) and indicate the right of a person who has suffered a violation as a result of the application of the contested provisions of the law, as well as determine the provision of the Constitution of Ukraine, which proclaims such a right.

It is quite obvious that the constitutional complaint is aimed at protecting not all rights, but only those defined by the Constitution of Ukraine. Other rights (those not defined by the Fundamental Law of Ukraine) are subject to protection by courts in the judicial system of Ukraine, and the guarantee of this protection is the provisions of Part 1 of Article 55 of the Constitution of Ukraine, according to which "human and civil rights and freedoms are protected by court". Therewith, under Part 1 of Article 22 of the Fundamental Law of Ukraine, the rights and freedoms of human and citizen enshrined in this Constitution are not exhaustive. This means that the catalogue of human rights enshrined in Section II of the said act is not closed. These are implicit rights, i.e., those that are not directly stipulated in the text of the Fundamental Law of Ukraine but follow from it.

8) The provisions of the Law oblige the author of the petition to indicate all information about the documents referred to in the constitutional complaint and to provide copies thereof. In addition, all documents and materials attached to the constitutional complaint must be indicated in the list of such documents and materials that are attached.

9) A copy of the final court decision in the case of the subject of the right to a constitutional complaint, certified in accordance with the established procedure by the court that approved it, must be attached to the materials of the constitutional complaint. Attaching a copy, a photocopy from a duly certified copy extracts from the Unified State Register of Judgments will not be considered compliance with this requirement of the Law ("The absence in the case file of a duly certified copy of the final court decision in the case of the subject of the right to a constitutional complaint is a significant formal defect and serves as the basis for the return of the constitutional complaint to the author of the petition by the head of the Secretariat of the Constitutional Court of Ukraine, as stipulated in Paragraph 1 of Part 3 of Article 57 of the Law" (decision of the Third Board of the First Senate of the Constitutional Court of Ukraine No. 793(I)/2018 of April 12, 2018 (Gultai and Hristova 2017).

TYPICAL MISTAKES THAT INDIVIDUALS MAKE WHEN DRAFTING AND FILING CONSTITUTIONAL COMPLAINTS

The mechanism of legislative settlement of the issues raised and the existing approaches to the preliminary examination of constitutional complaints allow not only to help avoid overloading the Court with complaints that do not meet the formal requirements of the Law but also to enable the subjects of the right to a constitutional complaint to eliminate such shortcomings, to bring the petition in compliance with the requirements of the Law, which is a necessary condition for its further consideration by the Court.

Each person, upon return of their constitutional complaint (in case of non-compliance with the requirements of the Law), is provided with explanations indicating which requirements of the Law this complaint failed to meet, as well as the possibility of re-applying to the Court in compliance with the Law. An analysis of the documents and materials available, in particular on the Court's official website, allows identifying the typical errors made by the authors of the constitutional complaints, which boil down to the fact that:

1) issues that cannot be the object of a constitutional complaint are raised (disagreement is expressed and decisions of courts in the judicial system of Ukraine are challenged, actions of state bodies and their officials, subordinate legislation, provisions of legislative acts that were not applied in the final court decision in the case of a person, etc. are appealed against); 
2) the subject of the constitutional review is not determined, i.e., specific provisions of the law of Ukraine that are to be reviewed for compliance with the Constitution of Ukraine and/or specific provisions of the Constitution of Ukraine for compliance with which the law of Ukraine is to be reviewed;

3) no arguments are given specifically about the unconstitutionality of the law of Ukraine (its individual provisions) and/or the human right guaranteed by the Constitution of Ukraine is not indicated, which has been violated as a result of the application of the contested provisions of the law;

4) information on documents and materials referred to by persons is not indicated, their copies are not provided;

5) a copy of the final court decision certified in accordance with the established procedure by the court that adopted it shall not be attached to the materials of the constitutional complaint (copies/photocopies of such decision shall be provided);

6) quite often constitutional complaints are signed by the representatives of the applicants and not by the subjects of the right to a constitutional complaint personally as required by law.

\section{CONSEQUENCES OF CONSIDERATION OF A CONSTITUTIONAL COMPLAINT BY THE CONSTITUTIONAL COURT OF UKRAINE}

The main legally significant consequence of the decision of the Constitutional Court of Ukraine on a constitutional complaint occurs for the final court decision in the case of the subject of the right to a constitutional complaint. The analysis of this issue is primarily related to the statutorily determined effect of acts of the Constitutional Court of Ukraine in general and with regard to decisions on constitutional complaints in particular. In general, all the variety of approaches available in different countries to determine the time of entry into force of acts of constitutional courts is traditionally divided into three groups: ex tunc ("from the beginning"), ex nunc ("from now on") and pro futuro ("for the future") (Ruling of the... 2018b; Ruling of the... 2018f). Accordingly, the doctrine of the nullity of acts recognised as unconstitutional is opposed to the doctrine of their invalidity. This creates a dilemma between doctrinal coherence and legal security and certainty. If in the first case, acts recognised as unconstitutional are considered as acts that have never been part of the legal system, in the second case, unconstitutional acts become invalid either from the moment the constitutional court makes a decision or from the one determined by it in deciding the moment in the future. Under this approach, the decision of the constitutional court has no retroactive effect on those (law-making, law-enforcement) acts that are based on an unconstitutional act, and they remain valid in the past (Ruling of the... 2018e; Karmaza et al. 2018).

Based on the need to ensure legal security and certainty, most states, in determining the time of entry into force of acts of constitutional courts, presumably apply the principle of ex nunc and with some reservations - pro futuro. And even in those states that are guided by the principle of ex tunc, its scope is strictly limited and, as a general rule, does not apply to final court decisions.

At the same time, the choice between these approaches directly affects a person's interest in filing a constitutional complaint with a body of constitutional jurisdiction and the associated expectations. Therefore, in different countries, either the retroactive effect of the decision of the constitutional court to apply in the case of the applicant or, more often, the decision of the constitutional court with certain significant reservations are recognised as grounds for reviewing final judgments, especially in criminal cases (Karmaza 2018; Abramov 2018). The above gives grounds to draw two important conclusions: firstly, the determination of the effect in time of acts of the constitutional court in general, and the decision on the constitutional complaint for the applicant, in particular, may not coincide; secondly, in the case of consolidating the acts of the constitutional court on an ex nunc principle, exceptions to the general rule are possible.

Currently, according to Part 2 of Article 152 of the Constitution of Ukraine, laws, other acts or their individual provisions that are declared unconstitutional shall cease to be valid from the date of the Constitutional Court's decision on their unconstitutionality, unless otherwise established by the decision. This means that the decisions of the Constitutional Court of Ukraine operate on an ex nunc basis. In other words, a legal act recognised by the Constitutional Court of Ukraine as inconsistent with the Constitution of Ukraine shall cease to be valid and shall 
not be applicable from the date of adoption of the relevant decision (European Court of... 2006).

At the same time, the Constitutional Court of Ukraine may determine in its decision a certain moment in the future when such an unconstitutional legal act will expire. That is, at the discretion of the Constitutional Court of Ukraine itself, the pro futuro principle may be applied to certain decisions as an exception.

Thus, for example, in the decision on the case on the constitutional petition of the Commissioner of the Verkhovna Rada of Ukraine for Human Rights regarding the compliance with the Constitution of Ukraine (constitutionality) of part 6 of Article 216 of the Criminal Procedural Code of Ukraine, the Constitutional Court of Ukraine indicated that the above provision becomes invalid after three months from the date of the adoption of a decision No. 3-r/2018 of April 24, 2018 by the Constitutional Court of Ukraine (European Commission for... 2011). Therewith, neither the Constitution of Ukraine nor the Law contain exceptions to the effect of decisions of the Constitutional Court of Ukraine, including those adopted in cases of constitutional complaints: the application of the ex tunc principle by these regulations in any circumstances is not provided. At the same time, according to paragraph 1 of Part 3 of Article 423 of the Civil Procedural Code of Ukraine (in the current version of 03.10.2017) "the unconstitutionality (constitutionality) of a law, other legal act or their separate provision established by the Constitutional Court of Ukraine, applied (not applied) by the court when deciding the case, if the court's decision has not yet been implemented" is defined as one of the exceptional grounds for reviewing court decisions that ended the consideration of the case and which came into force.

The unconstitutionality of a legal act or its separate provision established by the Constitutional Court of Ukraine presupposes another legally significant result. In particular, in accordance with Part 3 of Article 152 of the Constitution of Ukraine, material or moral damage caused to individuals or legal entities by acts and actions recognised as unconstitutional shall be reimbursed by the state in accordance with the procedure established by law.

In the aspect of restoring the violated rights of a particular person, several fundamentally important issues immediately arise here:
1) is there currently in Ukraine the procedure for compensation for material or moral harm caused to a person, acts and actions that are recognised as unconstitutional?

2) whether the provisions of Article 1175 of the Civil Code of Ukraine apply to the relevant relations, despite the substantive discrepancies in the wording of the Constitution and the Civil Code of Ukraine of the obligation to compensate for the harm caused ("damage caused ... by acts and actions that have been declared unconstitutional" and, accordingly, "damage caused ... by the adoption by a public authority ... of a regulation that has been declared illegal and repealed")?

3) how are the provisions of Part 3 of Article 152 and Part 2 of Article 152 of the Constitution of Ukraine consistent with each other, according to which laws, other acts or their individual provisions, recognised as unconstitutional, become invalid from the day the Constitutional Court of Ukraine takes a decision on their unconstitutionality, unless otherwise established by the decision itself, but not earlier than the day of its adoption?

Analysis of law enforcement practice indicates that despite the fact that twenty-three years after the adoption of the Constitution of Ukraine the state has not performed the positive obligation to adopt the relevant law (See: subpara. 5 para. 3.3. of the motivating part of the Decision of the Constitutional Court of Ukraine No. 25-rp/2009 of October 7, 2009 (On Amendments to... 2016)), which should determine the procedure and conditions of such compensation, courts apply the provisions of Part 3 of Article 152 of the Constitution of Ukraine as a rule of direct action and decide cases on the merits of the claimed claims.

Thus, based on the inadmissibility of refusal to consider the case on the grounds of absence, incompleteness, vagueness, the inconsistency of the legislation governing the disputed relationship, the courts indicate that the absence of the law cannot be grounds for dismissal, and serves as an excuse to apply the analogy of law, and in the absence of such a legal provision - an analogy of law, because Part 3 of Article 8 of the Constitution of Ukraine establishes that the provisions of the Constitution are directly applicable.

Accordingly, the unconstitutionality of the law established by the Constitutional Court of Ukraine is 
recognised by the courts as the basis for applying the consequences stipulated in Article 1175 of the Civil Code of Ukraine, since the civil liability regulated by this provision in the form of compensation for harm caused by the adoption of regulations recognised as unlawful also applies to cases of recognition of the laws of Ukraine as unconstitutional. In addition, the courts decide the competition of the provisions of the Constitution of Ukraine in favour of Part 3 of Article 152 of the Constitution of Ukraine as a special provision, pointing out that the damage caused to the plaintiffs by unconstitutional regulations must be compensated by the state.

Among all the variety of issues caused by the introduction in Ukraine of direct access of individuals and legal entities under private law to the body of constitutional jurisdiction, one can single out at least one issue that a priori was rather optimistically resolved by the academic community, despite its extreme complexity (Polovchenko 2019; European Court of... 2007c). This refers to the possibility of a constitutional complaint to act as an effective domestic remedy, which must be exhausted before applying for the protection of rights and freedoms to the European Court of Human Rights. Objectively assessing such positions, it should be noted that, first of all, they testified to conceptual views regarding the expected legislative regulation of the grounds, procedure and legally significant consequences of exercising the right to appeal to the Constitutional Court of Ukraine with a constitutional complaint. Accordingly, prior to the adoption of the Law by the Ukrainian Parliament in July 2017 , it referred to considerations that had the nature of de lege ferenda.

Even after the entry into force, some lawyers, probably out of inertia, categorically argued that "if the constitutional complaint starts working at full capacity, this will certainly reduce the number of applications submitted to the ECHR, significantly strengthening the national systems of judicial system and human rights protection" (On the Constitutional... 2017). At present, the latter statement is premature and erroneous, because, first of all, the Law de lege lata does not and cannot contain provisions that would provide undeniable arguments for this. To determine whether the model of constitutional complaint introduced in Ukraine provides preventive and compensatory aspects of the legal protection of fundamental rights and freedoms (which is critical for its identification as a national "filter" before the European Court of Human Rights according to the Venice Commission clause
(Karmaza 2018)), it is clearly not enough to analyse the provisions of the special law exclusively. The relevant provisions of national legislation, in particular procedural law, as well as, admittedly, national law enforcement practice should be analysed as well. It is this systematic approach in determining the effectiveness of national remedies that the European Court of Human Rights adheres to in case of any doubt (The Constitution of... 1996; Mavčič 2018).

Therewith, it is important that the powers granted to the constitutional court ensure effective decisionmaking (Decision of the... 2018). If the Constitutional Court is unable to reach a decision due to lack of procedural guarantees, or because of their ineffectiveness, this will lead to "[restricting] the essence of the right to access to court... [and depriving] the applicant of the effective right to a final decision on the applicant's constitutional complaint" (Decision of the... 2016).

In general, it seems that when deciding on the effectiveness of the model of constitutional complaint in Ukraine as a domestic remedy, which must be exhausted before applying to the European Court of Human Rights, the latter, among other things, will be guided by a "two-step approach". This approach involves determining the effectiveness of a constitutional complaint, depending on the applicant's ability to demand a re-examination of the case by the court, including the reopening of the proceedings, in accordance with the violation established by the decision of the Constitutional Court (Decision of 2018).

Undoubtedly, the decision made by the European Court of Human Rights, which will provide a systematic assessment of the effectiveness of a constitutional complaint as a remedy, will have far-reaching consequences for both law-making and law enforcement activities in Ukraine (Novitsky 2018).

\section{CONCLUSIONS}

The analysis of theoretical aspects, legislative regulation and practice of the Constitutional Court of Ukraine allows expressing the following conclusions.

The protection of subjective civil rights is carried out as a general rule in accordance with legal regulations, i.e., it is presumed that the law (in a broad sense) is legal. In this case, the judge has discretionary powers over the non-application of the law, which contradicts the principle of the rule of law with appropriate legal 
consequences (for example, Article 10 of the Civil Procedural Code of Ukraine), but in any case, the decision is made by law. Thus, subjective rights and interests established by law may be violated, unrecognised or challenged only at the stages of legal implementation (mainly between legally equal persons) or law enforcement (violation of rights by public authorities). The powers of the Constitutional Court of Ukraine come down to constitutionality at the stage of legal regulation, in fact, evaluating the compliance with the Constitution of Ukraine of the probable cause of a legal dispute that cannot be resolved in a fair manner based on a provision that is the subject of constitutional control.

Decisions of the Constitutional Court of Ukraine show signs of protection of collective (group) rights and interests based on an appeal of both an individual and a legal entity, which in the future will serve the positive practice of human rights organisations. The prejudicial nature of the Court's decision, apart from ensuring the supremacy of the Constitution of Ukraine, contributes to the assertion of essential public interests.

In contrast to conventional judicial protection, which allows recognising, restoring rights or terminating their violations, decisions of the Constitutional Court of Ukraine strengthen the rights established by the Fundamental Law of Ukraine. Therewith, the specific features of the temporal effect of the Court's decisions only allow to compensate the material and moral damage caused by the law that was declared unconstitutional, although this provision is currently within the scope of scientific and practical discussion.

\section{REFERENCES}

Abramov, Ruslan, Koshkin, Andrey, Sokolov, Maxym, and Surilov, Mayir. 2018. "Transformation of the Public Administration System in the Context of Integration of the National Innovation Systems of the Union State". Espacios 39(14): Article number 5 .

Berestova, Iryna. 2018. Theoretical Principles of Protection of Public Interests in Civil Proceedings and Constitutional Proceedings. Kyiv: FOP Maslakov.

Borysova, Valentina, Ivanova, Kateryna, lurevych, Iryna, and Ovcharenko, Olena. 2019. "Judicial Protection of Civil Rights In Ukraine: National Experience Through The Prism Of European Standards". Journal of Advanced Research in Law and Economics 10(1):66-84.

Council of Europe. 2013. Guide to Good Practice in Respect of Domestic Remedies (https://www.echr.coe.int/Documents/ Pub_coe_domestics_remedies_ENG.pdf)

Dąbrowski, Ludwik. 2019. "Entitlement of Legal Entities to Hold Rights Under the Inter-American Human Rights Protection System". International Community Law Review 21(5):449462.

https://doi.org/10.1163/18719732-12341413
Decision of the Constitutional Court of Ukraine No. 12-рп/2013. 2013 (https://zakon.rada.gov.ua/laws/show/v012p710-13\#Text).

Decision of the Constitutional Court of Ukraine No. 15-рп/2000. 2004 (https://zakon.rada.gov.ua/laws/show/v015p710-00\#Text).

Decision of the Constitutional Court of Ukraine No. 25-pп/2009. 2009 (https://zakon.rada.gov.ua/laws/show/v025p710-09\#Text).

Decision of the Constitutional Court of Ukraine No. 3-p/2018. 2018 (https://zakon.rada.gov.ua/laws/show/v003p710-18\#Text).

Decision of the Supreme Commercial Court of Ukraine in the case No. 922/2110/16. $2016 \quad$ (https://reyestr.court.gov.ua/ Review/63759216).

Decision of the Supreme Court in the case No. 804/6859/16. 2018 (https://reyestr.court.gov.ua/Review/77910656).

Dzera, Olexsandr, Luts, Volodymyr, and Kuznetsova, Natalia. 2008. Scientific and practical commentary on the Civil Code of Ukraine. Kyiv: Yurinkom Inter.

European Commission for Democracy through Law. 2011. Study on individual access to constitutional justice (https://www.venice. coe.int/WebForms/documents/default.aspx?pdffile=CDLAD(2010)039rev-e).

European Court of Human Rights. 2000. Case of Kudła v. Poland No. 30210/96 (http://hudoc.echr.coe.int/eng?i=001-58920).

European Court of Human Rights. 2004. Case of Radio France and Others v. France. No. 53984/00 (http://hudoc.echr.coe.int/ eng? $i=001-61686$ ).

European Court of Human Rights. 2006. Sürmeli v. Germany No 75529/01 (http://hudoc.echr.coe.int/fre?i=001-75689).

European Court of Human Rights. 2007a. Affaire Kamil Uzun c. Turquie. Requête No. 37410/97 (http://hudoc.echr.coe.int/ eng?i=001-119849).

European Court of Human Rights. 2007b. Case of Islamic Republic of Iran Shipping Lines v. Turkey No. 40998/98 (http://hudoc. echr.coe.int/eng? $\mathrm{i}=001-83951$ )

European Court of Human Rights. 2007c. Marini v. Albania No. 3738/02 (http://hudoc.echr.coe.int/fre?i=001-84061).

European Court of Human Rights. 2008. Affaire Unédic c. France No. 20153/04 (http://hudoc.echr.coe.int/eng?i=001-90350).

European Court of Human Rights. 2010. Case of Ukraine-Tyumen v Ukraine No. 22603/02 (http://hudoc.echr.coe.int/eng?i=00183421).

Gubska, Alla. 2014. "Group and Other Representative Lawsuits: the Criteria for Differentiation". Legal Bulletin 33(4):81-87. https://doi.org/10.18372/2307-9061.33.8393

Gultai, Mykhaiko, and Hristova, Ganna. 2017. "Constitutional Complaint as a Domestic Remedy in the Context of Access to the European Court of Human Rights". Bulletin of the Constitutional Court of Ukraine 5:56-66.

Horodovenko, Victor, Pashkov, Vitaliy, and Udovyka, Larisa. 2020 "International Legal Instruments In The Field Of Bioethics And Their Impact On Protection Of Human Rights". Wiadomosci Lekarskie 73(7):1554-1560. https://doi.org/10.36740/WLek202007144

Karmaza, Oleksandra, Sarana, Sergiy, Fedorenko, Tetyana, Gurzhii, Taras, and Nefedova, Anna. 2018. "The Protection of Civil Rights and Interests in the Court". Journal of Advanced Research in Law and Economics 9(8):2622-2630.

Mavčič, Arne. (ed.) 2018. Constitutional Review Systems Around the World. Lake Mary: Vandeplas Publishing.

Novitsky, Vladislav. 2018. "The Guarantees of Human Rights and Freedoms in the European Union: the Experience for Ukraine". Journal of Advanced Research in Law and Economics 9(7):2397-2402

On Amendments to the Constitution of Ukraine (Regarding Justice): Law of Ukraine No. 1401-VIII. 2016. Information of the Verkhovna Rada of Ukraine, 28 (http://radabook.com/ відомості-верховної-ради-україни-електронний-архів/996відомості-верховної-ради-україни-№28-2016електронний-примірник-2) 
On the Constitutional Court of Ukraine: Law of Ukraine No 2136-VIII. 2017 (https://zakon.rada.gov.ua/laws/show/2136-19\#Text).

Polovchenko, Konstantine. 2019. "Constitutional Rights and Freedoms of National Minorities: the Experience of Serbia". Opcion 35(Special Issue 23):1433-1446.

Resolution of the First Panel of Judges of the Second Senate of the Constitutional Court of Ukraine No 174-1(II)/2018. 2018a. (http://www.ccu.gov.ua/docs/2223).

Resolution of the First Panel of Judges of the Second Senate of the Constitutional Court of Ukraine No. 59-1(II)/2018. 2018b (http://www.ccu.gov.ua/docs/2164).

Resolution of the Third Board of the First Senate of the Constitutional Court of Ukraine No. 79-3(I)/2018. 2018 (http://www.ccu.gov.ua/docs/2139).

Ruling of the First Senate of the Constitutional Court of Ukraine No. 20-y(I). 2018a (http://www.ccu.gov.ua/docs/2264).

Ruling of the First Senate of the Constitutional Court of Ukraine No. 55-y(I)/2018. 2018b (http://www.ccu.gov.ua/docs/2427).

Ruling of the Second Senate of the Constitutional Court of Ukraine No. 1-уп(II)/2018. 2018a (http://www.ccu.gov.ua/docs/2088).

Ruling of the Second Senate of the Constitutional Court of Ukraine No. 10-y(II)/2018. 2018b (http://www.ccu.gov.ua/docs/2245).

Ruling of the Second Senate of the Constitutional Court of Ukraine No. 17-y(II)/2018. 2018c (http://www.ccu.gov.ua/docs/2256).

Ruling of the Second Senate of the Constitutional Court of Ukraine No. 18-y(II)/2018. 2018d (http://www.ccu.gov.ua/docs/2257).

Ruling of the Second Senate of the Constitutional Court of Ukraine No. 23-y(II)/2018. 2018e (http://www.ccu.gov.ua/docs/2279).
Ruling of the Second Senate of the Constitutional Court of Ukraine No. 35-y(II)/2018. 2018f (http://www.ccu.gov.ua/docs/2378).

Sakara, Nataliia. 2017. "Content and Legal Nature of Legal Dispute". Scientific Bulletin of Uzhhorod National University. Law 46(1):63-68.

Savchyn, Mykhailo. 2018. "Doctrinal Problems of Introducing a Constitutional Complaint in Ukraine". Law of Ukraine 12:3955

Smolkova, Iraida, Vilkova, Tatyana, Maziuk, Roman, Nasonov, Sergey, and Nichiporenko, Alexander. 2018. "Prospects of Improving the Mechanism of Judicial Protection in Russian Criminal Proceedings: Issues of Theory and Practice". Russian Journal of Criminology 12(3):387-395. https://doi.org/10.17150/2500-4255.2018.12(3).387-395

Stavniychuk, Maryna, Ezerov, Albert, Zaporozhets, Vitaly, and Terletsky, Dmytro. 2019. Constitutional Complaint in the Activities Of A Lawyer. Kharkiv: Factor.

Steinberger, Helmut. 1994. European Commission for Democracy through Law. Models of Constitutional Jurisdiction (https://www.venice.coe.int/webforms/documents/default.asp $x$ ?pdffile=CDL-JU(1991)001-e)

The Constitution of Ukraine No. 254k/96-BP. 1996 (https://zakon.rada.gov.ua/laws/show/254к/96-вр\#Text).

Umbetov, Madiyar, Nurmaganbet, Ermek, Bitemirov, Kairat, Kalkashev, Nursultan, and Yeslamgaliyev, Zhaksylyk. 2020. Some aspects of legal regulation in international law: Human rights protection issues. Rivista Di Studi Sulla Sostenibilita 2020(1):479-495.

Received on 01-01-2021

Accepted on 25-01-2021

Published on 02-02-2021

DOI: https://doi.org/10.6000/1929-4409.2021.10.42

(c) 2021 Krupchan et al.; Licensee Lifescience Global.

This is an open access article licensed under the terms of the Creative Commons Attribution Non-Commercial License (http://creativecommons.org/licenses/by-nc/3.0/) which permits unrestricted, non-commercial use, distribution and reproduction in any medium, provided the work is properly cited. 